\title{
Phylogenetic Diversity and Host Specialization of Corynespora cassiicola Responsible for Emerging Target Spot Disease of Cotton and Other Crops in the Southeastern United States
}

\author{
Leilani G. Sumabat, Robert C. Kemerait, Jr., and Marin Talbot Brewer ${ }^{\dagger}$
}

First and third authors: Department of Plant Pathology, University of Georgia, Athens 30602; and second author: Department of Plant Pathology, University of Georgia, Tifton 31793.

Accepted for publication 11 February 2018.

\begin{abstract}
Corynespora cassiicola is a ubiquitous fungus causing emerging plant diseases worldwide, including target spot of cotton, soybean, and tomato, which have rapidly increased in incidence and severity throughout the southeastern United States. The objectives of this study were to understand the causes for the emerging target spot epidemics in the United States by comparing phylogenetic relationships of isolates from cotton, tomato, soybean, and other crop plants and ornamental hosts, and through the determination of the host range of isolates from emerging populations. Fifty-three isolates were sampled from plants in the southeastern United States and 1,380 nucleotides from four nuclear loci were sequenced. Additionally, sequences of the same loci from 23 isolates representing each of the distinct lineages of $C$. cassiicola described from previous

studies were included. Isolates clustered based on host of origin, regardless of the geographic location of sampling. There was no genetic diversity detected among isolates from cotton, which were genetically distinct from isolates from other host species. Furthermore, pathogenicity and virulence assays of 40 isolates from various hosts onto cotton, soybean, tomato, and cucumber showed that isolates from cotton were more aggressive to cotton than those from other hosts. Soybean and tomato were most susceptible to isolates that originated from the same host, providing evidence of host specialization. These results suggest that emerging target spot epidemics in the United States are caused by either the introduction of host-specific isolates or the evolution of more aggressive strains on each host.
\end{abstract}

Emerging diseases are a constant threat to plant production in the United States and abroad (Anderson et al. 2004). They are caused by pathogens that (i) are increasing in host range, geographic range, or incidence; (ii) have evolved new strains that are more aggressive, have overcome host resistance, or are resistant to fungicides or antibiotics; or (iii) are newly recognized. Emerging fungal pathogens, in particular, are of immediate threat to humans, animals, and plants, and are a serious threat to food security (Fisher et al. 2012). Drivers of emerging diseases include pathogen adaptation, pathogen introductions, increased host susceptibility, or environmental change. There are numerous cases of devastating emerging plant diseases caused by fungi, including the emergence of Puccinia graminis race $\mathrm{Ug} 99$, a strain of wheat stem rust that has overcome host resistance and is a global threat to food security (Singh et al. 2006); laurel wilt caused by Raffaelea lauricola, which was introduced from Asia (Harrington et al. 2011), has killed millions of bay laurels in the southeastern United States, and is impacting the Florida avocado industry (Mayfield et al. 2008); and the emergence and geographic expansion of an aggressive strain of Fusarium oxysporum $\mathrm{f}$. sp. cubense that is threatening the Cavendish banana clone (Butler 2013). Quite often emerging diseases caused by plant-pathogenic fungi result from the evolution of a new strain or introduction into a new range with naive hosts.

Target spot of cotton (Gossypium hirsutum), soybean (Glycine max), and tomato (Solanum lycopersicum), caused by Corynespora cassiicola (Berk. \& M. A. Curtis) C. T. Wei, have recently emerged

${ }^{\dagger}$ Corresponding author: M. T. Brewer; E-mail: mtbrewer@uga.edu

Funding: Funding for this project was provided by Cotton Incorporated.

*The $\boldsymbol{e}$-Xtra logo stands for "electronic extra" and indicates that one supplementary figure is published online.

(C) 2018 The American Phytopathological Society as serious diseases across the southeastern United States. The fungus $C$. cassiicola has long been known to cause target-like leaf spots on Upland cotton (Jones 1961; Onesirosan et al. 1975) but had not previously been noted to cause epidemics or be detrimental to yields. However, in 2008 in Georgia, severe premature defoliation of affected cotton leaves and significant yield losses were attributed to C. cassiicola (Fulmer et al. 2012). Target spot emergence in cotton expanded geographically with great rapidity and has now been observed in Alabama (Campbell et al. 2012), Florida, Louisiana (Price et al. 2015), North Carolina (Edmisten 2012), South Carolina, Tennessee (Butler et al. 2016), Arkansas, Mississippi, and Virginia (Mehl and Phipps 2013). Yield losses range from 5 to $40 \%$ (Conner et al. 2013; Hagan 2014) and lint can be reduced by $224 \mathrm{~kg} / \mathrm{ha}$. Interestingly, an increase in target spot of soybean by $C$. cassiicola has been observed in the southeastern United States (Bennett 2016; Faske 2016; Koenning et al. 2006). Similar to target spot of cotton, target spot of soybean had historically been a minor concern in the United States but caused significant yield losses in Brazil and Bolivia (Wrather et al. 2001). Moreover, during the past 20 years, C. cassiicola has emerged as the most serious foliar and fruit pathogen of tomato in Florida (Schlub et al. 2009). There are several reports of occurrence on vegetable crops and ornamental plants, particularly cucumber (Cucumis sativa) and Hydrangea spp. (Blazquez 1967, 1972). Since the earliest recorded incidence of target spot in the southeastern United States (Olive et al. 1945), there has been a rapid increase in the number of reports globally (Galbieri et al. 2014; Shimomoto et al. 2011; Wei et al. 2014). It is not clear why target spot has recently increased in severity and incidence on cotton, soybean, and tomato in the southeastern United States.

Corynespora cassiicola is a common, necrotrophic pathogen in the tropics and subtropics, where it causes major economic losses in more than 70 countries throughout the world (Dixon et al. 2009). It is an asexual fungus with a very broad host range infecting the leaves, 
stems, flowers, fruit, or roots of over 300 plant species, including crop plants, ornamentals, and weeds (Farr and Rossman 2017). Economically important plants that are affected, in addition to cotton, soybean, tomato, cucumber, and Hydrangea spp., include rubber tree (Hevea brasiliensis), bean (Phaseolus vulgaris), lettuce (Lactuca sativa), basil (Ocimum basilicum), bell pepper (Capsicum annuum), sweet potato (Ipomoea batatas), lantana (Lantana camara), cowpea (Vigna unguiculata), and papaya (Carica papaya). In addition to being a pathogen, Corynespora cassiicola can be a saprophyte (Kingsland 1986; Lee et al. 2004) or endophyte (Collado et al. 1999; Déon et al. 2012; Promputtha et al. 2007; Suryanarayanan et al. 2002), and has also been found associated with animals, including soybean cyst nematode (Carris et al. 1986), and as subcutaneous skin infections and corneal infections of humans (Huang et al. 2010; Mahgoub 1969).

The most studied and one of the most devastating diseases caused by $C$. cassiicola is Corynespora leaf fall disease of rubber (Silva et al. 2003). Historically, C. cassiicola was considered a weak pathogen of rubber (Newsam 1960) but emerged as a severe pathogen during epidemics in Indonesia in 1975 (Chee 1990). It increased its range in the 1980s, spreading throughout Thailand, Malaysia, Sri Lanka, and Africa (Chee 1990). It is currently increasing in importance in China, with disease incidence at 94\% (Qi et al. 2011). Corynespora leaf fall disease now occurs everywhere rubber is grown in Asia and Africa, causing severe economic losses from necrotic lesions that lead to defoliation (Chee 1990). It has also been observed to occur on rubber in Brazil; however, it does not cause any major problem because it exists as an endophyte (Déon et al. 2012). A trend that is evident among emerging diseases caused by $C$. cassiicola is that the host plants were historically affected by the fungus, often in the same regions where the diseases emerged, but the diseases rapidly went from being minor problems to major diseases.

An understanding of the population biology of emerging pathogens may provide reasons underlying disease emergence, which may, in turn, lead to effective disease management strategies. The most comprehensive study on the population biology of $C$. cassiicola investigated host specialization and phylogenetic diversity within the species (Dixon et al. 2009). Phylogenetic analyses of 143 isolates sampled from 68 plant species across different regions of the world revealed six phylogenetic lineages (PL) that were widely distributed across geographic regions but correlated with host of origin and pathogenicity. However, cotton isolates were not included in the sampling, and the two soybean isolates that were used were from outside the United States. Tomato isolates sampled from the United States were found to belong to a lineage (PL4) with tomato isolates from Brazil, Guam, Palau, and Saipan. However, tomato isolates found in American Samoa and Yap belonged to a different lineage (PL3). Another phylogenetic study of diverse isolates of C. cassiicola, including an isolate from cotton in Brazil (Déon et al. 2014), revealed that aggressiveness was based on the class of the cassiicolin toxin.

Understanding disease emergence requires knowledge of pathogen biology and its interaction with hosts (Anderson et al. 2004); however, no known studies have been reported that compare the genetic diversity and pathogenicity of $C$. cassiicola causing emerging epidemics of cotton, soybean, and tomato in the southeastern United States. It is unclear whether these epidemics are caused by the same or different populations of $C$. cassiicola. The objectives of this study were to (i) determine the evolutionary relationships and genetic diversity of C. cassiicola on cotton, soybean, tomato, and other hosts in the southeastern United States; (ii) identify whether these epidemics are caused by the same or different populations; and (iii) compare the host range of isolates from the United States on economically important crops. These phylogenetic relationships and host range of isolates of $C$. cassiicola from cotton will be compared with isolates from other hosts, particularly those present in the southeastern United States. This will assist in determining whether disease emergence is the result of an introduction, evolution of a more aggressive strain, change in host susceptibility, or changes in environmental factors.

\section{MATERIALS AND METHODS}

Sampling, fungal isolations, and DNA extraction. C. cassiicola was sampled across the southeastern United States from different cultivars of cotton, soybean, and tomato, as well as cucumber, Hydrangea spp., Mandevilla spp., pepper, and sesame (Sesamum indicum) with target spot symptoms (Table 1). Isolates were obtained from symptomatic leaves by excising a $1-\mathrm{cm}^{2}$ lesion margin from each leaf. The leaf tissue was surface disinfested in $0.6 \% \mathrm{NaClO}$ for $1 \mathrm{~min}$, rinsed twice with sterile distilled $\mathrm{H}_{2} \mathrm{O}$, and blotted dry with a lint-free wipe. The surface-disinfested tissue was cut into four pieces and placed onto quarter-strength potato dextrose agar (qPDA) in a 100-mm Petri dish. After 3 days of growth at $25^{\circ} \mathrm{C}$ in the dark, an agar plug of actively growing hyphae from the edge of a colony was transferred to a new Petri dish of qPDA. Isolates were maintained at $-20^{\circ} \mathrm{C}$ on filter paper.

Total genomic DNA was extracted using a rapid, high-yielding mini-prep method for fungi (Lee 1988). Isolates were grown in 60-mm Petri dishes on qPDA overlaid with sterile cellophane for 5 days in the dark at $25^{\circ} \mathrm{C}$. Approximately $5 \mathrm{~cm}^{2}$ of mycelium was scraped from the cellophane surface with a sterile spatula and added to $1 \mathrm{ml}$ of lysis buffer (0.5 M EDTA [pH 8], 1 M Tris [pH 8], 20\% sodium dodecyl sulfate, proteinase $\mathrm{K}$ at $20 \mathrm{mg} / \mathrm{ml}$, and $1 \%$ sodium bisulfite), vortexed for $1 \mathrm{~min}$, and incubated at $65^{\circ} \mathrm{C}$ for $15 \mathrm{~min}$. Samples were briefly vortexed and centrifuged at $14,000 \times g$ for $5 \mathrm{~min}$. The resulting supernatant was transferred to a sterile microcentrifuge tube and $200 \mu \mathrm{l}$ of $7.5 \mathrm{M} \mathrm{NH}_{4} \mathrm{OAc}$ was added. The mixture was vortexed on high for $10 \mathrm{~s}$, placed on ice for $15 \mathrm{~min}$, and centrifuged at $14,000 \times g$ for $3 \mathrm{~min}$. The supernatant was transferred to a sterile microcentrifuge tube and $700 \mu \mathrm{l}$ of isopropanol was added; then, the mixture was briefly vortexed and centrifuged at $14,000 \times g$ for $5 \mathrm{~min}$. The supernatant was carefully discarded and the pellet of DNA was rinsed twice with $1 \mathrm{ml} \mathrm{70 \%} \mathrm{EtOH}$, air dried, and resuspended in $50 \mu \mathrm{l}$ of sterile distilled $\mathrm{H}_{2} \mathrm{O}$. DNA was stored at $-20^{\circ} \mathrm{C}$.

Multilocus sequencing. Four nuclear loci previously identified in $C$. cassiicola (Dixon et al. 2009) were amplified by polymerase chain reaction (PCR) and sequenced for 53 isolates from diverse hosts of origin and geographic locations in the southeastern United States (Table 1). In all, 20 isolates from cotton, 12 isolates from soybean, 11 isolates from tomato, 3 isolates from Hydrangea, 3 isolates from pepper, 2 isolates from Mandevilla, and 1 isolate each from cucumber and sesame were sequenced for the internal transcribed spacer (ITS) region of the ribosomal DNA, actin, and two hypervariable loci ( caa5 and $g a 4)$ The primers used included ITS1 (5'-TCCGTAGGTGAAC CTGCGG-3') and ITS4 (5'-TCCTCCGCTTATTGATATGC-3') for ITS (White et al. 1990), ACT-512F (5'-ATGTGCAAGGCCGGTTT CGC-3') and ACT-783R (5'-TACGAGTCCTTCTGGCCCAT-3') for actin (Carbone and Kohn 1999), GA4-F (5'-CCTGCTCC GACTTTGTTGAG-3') and GA4-R (5'-GTCTGGGAGCAGCAA AGACT-3') for $g a 4$, and CAA5-F (5'-GTCCACAAGTGGAACC TCGT-3') and CAA5-R (5'-CCTCGTCTGCCAGTTCTTCT-3') for caa5 (Dixon et al. 2009). PCR was carried out in $25-\mu$ l reactions consisting of $2.5 \mu \mathrm{l}$ of $10 \times$ ExTaq buffer (Takara Bio, Inc.), $2.5 \mu \mathrm{l}$ of $2.5 \mathrm{mM}$ dNTP, $1.25 \mu \mathrm{l}$ of each $10 \mu \mathrm{M}$ primer, $0.3 \mu \mathrm{l}$ of ExTaq (Takara Bio, Inc.), and $1 \mu \mathrm{l}$ of DNA template (10 to $200 \mathrm{ng} / \mu \mathrm{l})$. Thermal cycling conditions for ITS, ga4, and caa5 consisted of an initial denaturation at $94^{\circ} \mathrm{C}$ for $2 \mathrm{~min} ; 40$ cycles of $94^{\circ} \mathrm{C}$ for $30 \mathrm{~s}, 55^{\circ} \mathrm{C}$ for $30 \mathrm{~s}$, and $72^{\circ} \mathrm{C}$ for 30 ; followed by $72^{\circ} \mathrm{C}$ for $5 \mathrm{~min}$. Similar thermal cycling conditions were used for actin, except the annealing temperature was $61^{\circ} \mathrm{C}$ and there were 45 cycles. Amplification of fragments of the expected sizes was confirmed by electrophoresis on a $1 \%$ (wt/vol) agarose gel. PCR product purification was done using ExoSAP-IT PCR product cleanup reagent (Affymetrix). DNA fragments were sent for Sanger sequencing at the Georgia Genomics Facility in Athens, GA, using Big Dye Terminator chemistry and an Applied Biosystems 3730 DNA Analyzer. All PCR products were sequenced in both directions using the same primers used for PCR.

Phylogenetic analyses. Sequences were visually edited in Geneious v.7 (Biomatters) and aligned using ClustalW (Thompson 
et al. 2002). All sequences were deposited at GenBank under accession numbers MF320502 to MF320554 for ITS, MF320356 to MF320395 for actin, MF320449 to MF320501 for ga4, and MF320396 to MF320448 for caa5. In addition to sequences obtained in this study, sequences of each of the four loci from isolates representative of the previously determined lineages (Dixon et al. 2009) were obtained from GenBank for comparison. C. olivacea (CBS 291.74) from Tilia spp. was used as the outgroup. Alignments were deposited in TreeBASE under accession number 21997.

Phylogenetic relationships were inferred using maximum-likelihood (ML) in MEGA5 (Tamura et al. 2011) and Bayesian inference (BI) in MrBayes (Ronquist and Huelsenbeck 2003). Analyses were conducted for each locus individually and for the four loci combined.
Evolutionary models of nucleotide substitution were determined based on goodness-of-fit in MEGA5. The Tamura three-parameter model of evolution assuming a $\gamma$ distribution, as determined most appropriate in MEGA5, was implemented on the combined dataset. For the individual locus datasets, the following best-fit models of evolution were identified in MEGA5: Tamura three-parameter assuming a $\gamma$ distribution was used for actin and caa5, Tamura three-parameter with invariable site was used for ga4, and Kimura two-parameter model was used for ITS. For ML, support for each node was determined by 500 bootstrap replicates. For BI, four incrementally heated Markov chains were run, and samples were taken every 100 generations for 5,000,000 generations. Phylogenetic congruence of the four loci was evaluated using the Shimodaira-Hasegawa ( $\mathrm{SH})$

TABLE 1. Host plant, geographic location of origin, and phylogenetic lineage (PL) of Corynespora cassiicola isolates used in this study

\begin{tabular}{|c|c|c|c|}
\hline Host plant of origin & Geographical location of origin & Isolate names ${ }^{y}$ & $\mathrm{PL}^{\mathrm{z}}$ \\
\hline Upland cotton (Gossypium hirsutum) & Baldwin County, AL & CAL-2a & 1 \\
\hline Upland cotton & Elmore County, AL & CAL- $3^{\mathrm{a}}$ & 1 \\
\hline Upland cotton & Macon County, AL & CAL-4 & 1 \\
\hline Upland cotton & Jacksonville County, FL & $\mathrm{FlM}^{\mathrm{a}}$, FlM2, FlM3 & $1,1,1$ \\
\hline Upland cotton & Atkinson County, GA & $\mathrm{CA} 1^{\mathrm{b}}$ & ns \\
\hline Upland cotton & Bishop County, GA & $\mathrm{CB} 1^{\mathrm{b}}$ & ns \\
\hline Upland cotton & Coffee County, GA & $\mathrm{CCo}^{\mathrm{b}}$ & ns \\
\hline Upland cotton & Mitchell County, GA & $\mathrm{CM} 1^{\mathrm{b}}$ & ns \\
\hline Upland cotton & Pierce County, GA & $\mathrm{CPi}^{\mathrm{b}}, \mathrm{CPi} 2-1^{\mathrm{b}}, \mathrm{CPi} 8-1^{\mathrm{a}}, \mathrm{CPi} 8-2$ & ns,ns, 1,1 \\
\hline Upland cotton & Tift County, GA & $\mathrm{CT} 1^{\mathrm{a}}, \mathrm{CT} 2, \mathrm{CT} 2-1^{\mathrm{b}}$ & $1,1, \mathrm{~ns}$ \\
\hline Upland cotton & Ware County, GA & $\mathrm{CW} 1^{\mathrm{b}}$ & ns \\
\hline Upland cotton & Rapides Parish, LA & CLAa-2, CLAb-2a & 1,1 \\
\hline Upland cotton & Madison County, TN & $\mathrm{CTs} 1^{\mathrm{a}}, \mathrm{CTs} 2, \mathrm{CTs} 3$ & $1,1,1$ \\
\hline Upland cotton & Suffolk, VA & $\mathrm{CVa}^{\mathrm{a}}, \mathrm{CVa} 2, \mathrm{CVa} 3, \mathrm{CVa} 4, \mathrm{CVa} 5$ & $1,1,1,1,1$ \\
\hline Soybean (Glycine max) & Berrien County, GA & $\mathrm{SB} 1^{\mathrm{b}}$ & ns \\
\hline Soybean & Calhoun County, GA & GaT-S2 ${ }^{b}$, GaT-S3 $^{\mathrm{a}}$ & $\mathrm{ns}, 1$ \\
\hline Soybean & Marion County, GA & $\mathrm{SMR}^{\mathrm{a}}{ }^{,}, \mathrm{SMR} 2^{\mathrm{a}}, \mathrm{SMR} 3$ & $1,1,1$ \\
\hline Soybean & Tift County, GA & SsTa1 ${ }^{\mathrm{a}}, \mathrm{SsTa} 2, \mathrm{SsTa} 3$ & $1,1,1$ \\
\hline Soybean & Madison County, TN & $\begin{array}{l}\text { STNa-1, STNa-2, STNc-3, STNd-3, } \\
\text { STNd-4 }{ }^{\text {b }, ~ S T s ~} 2, \text { STs }^{\text {b }}\end{array}$ & $\begin{array}{c}1,1,1^{*}, 1 \\
\mathrm{~ns}, 1, \mathrm{~ns}\end{array}$ \\
\hline Soybean & Suffolk, VA & SVal $1^{b}$ & ns \\
\hline Sesame (Sesamum indicum) & Tift County, GA & SeF-1 & 1 \\
\hline Hydrangea sp. & Oconee County, GA & $\mathrm{GaA}-\mathrm{H} 1^{\mathrm{a}}, \mathrm{GaA}-\mathrm{H} 2^{\mathrm{a}}$ &,$- 1 *$ \\
\hline Hydrangea sp. & Tift County, GA & $\mathrm{HT} 1^{\mathrm{b}}, \mathrm{HGa}^{\mathrm{a}}$ & ns, - \\
\hline Tomato (Solanum lycopersicum) & Collier County, FL & $1555^{\mathrm{a}}$ & 4 \\
\hline Tomato & Hillsborough County, FL & $108^{\mathrm{a}}, 1551^{\mathrm{a}}, 7 \mathrm{p}^{\mathrm{a}}, 1343^{\mathrm{a}}$ & $4,4^{*}, 4^{*}, 4^{*}$ \\
\hline Tomato & Cairo County, GA & TCf1 $^{\mathrm{a}}, \mathrm{TCf}_{2}, \mathrm{TCl1}^{\mathrm{a}}, \mathrm{TCl} 2, \mathrm{TCl} 3, \mathrm{TCl} 4$ & $4^{*}, 4,4^{*}, 4^{*}, 4^{*}, 4^{*}$ \\
\hline Pepper (Capsicum annuиm) & Echols County, GA & $\mathrm{PE} 1^{\mathrm{a}}, \mathrm{PE} 2$ & $4 *, 4$ \\
\hline Pepper & Tift County, GA & PE2-1 ${ }^{\mathrm{a}}$ & 4 \\
\hline Cucumber (Cucumis sativus) & Colquitt County, GA & $\mathrm{CuC} 1^{\mathrm{a}}$ & $4 *$ \\
\hline Mandevilla sp. & Oconee County, GA & $\mathrm{GaA}-\mathrm{Hb} 1^{\mathrm{a}}, \mathrm{GaA}-\mathrm{Hb} 2$ & 4,4 \\
\hline Tomato & American Samoa & AS49c & 3.1 \\
\hline Cuсurbita реро & American Samoa & $\mathrm{AS} 119^{\mathrm{c}}$ & 3.2 \\
\hline Cucumber & Brazil & ATI11 ${ }^{\mathrm{d}}$ & 1 \\
\hline Soybean & Brazil & ATI13 ${ }^{\mathrm{d}}$ & 1 \\
\hline Soybean & Brazil & $493 \mathrm{AA}^{\mathrm{d}}$ & 1 \\
\hline Soybean & Brazil & $777 \mathrm{AA}^{\mathrm{d}}$ & 1 \\
\hline Soybean & Brazil & RUD $^{d}$ & 1 \\
\hline Upland cotton & Brazil & ATI17 ${ }^{\mathrm{d}}$ & 1 \\
\hline Plectranthus barbatus & Brazil & (BZ)RWB321 ${ }^{\mathrm{c}}$ & 5 \\
\hline Blueberry (Vaccinium corymbosum) & Florida & FL51 ${ }^{\mathrm{c}}$ & - \\
\hline Codiaeum variegatum & Guam & GU10 & 1.3 \\
\hline Allamanda cathartica & Guam & GU38 ${ }^{c}$ & 2 \\
\hline Acanthus ilicifolius & Guam & GU79c & 3 \\
\hline Plectranthus ambionicus & Guam & GU110c & 3 \\
\hline Soybean & Guam & GU112c & 3.3 \\
\hline Rubber (Hevea brasiliensis) & Malaysia & $(\mathrm{MY}) \mathrm{CLN} 16^{\mathrm{c}}$ & 1.2 \\
\hline Tomato & Mississippi & $\operatorname{MS} 31^{\mathrm{c}}$ & 4 \\
\hline Papaya (Carica papaya) & Palau, Micronesia & PW $48^{c}$ & 1.1 \\
\hline Episcia reptans & Palau, Micronesia & PW83c & 1 \\
\hline Luffa acutangula & Palau, Micronesia & PW91 ${ }^{\mathrm{c}}$ & 1 \\
\hline Lantana camara & Saipan, Northern Mariana Islands & SN59c & 1.5 \\
\hline Saintpaulia ionantha & Tennessee & $\mathrm{TN} 13-3^{\mathrm{c}}$ & 6 \\
\hline Cucumber & Yap, Micronesia & YP26c & 1 \\
\hline
\end{tabular}

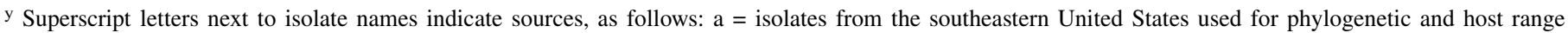
analyses, $\mathrm{b}=$ isolates from the southeastern United States used only for host range analyses, $\mathrm{c}=$ sequences obtained from GenBank (Dixon et al. 2009), and d= sequences obtained from GenBank (Déon et al. 2014).

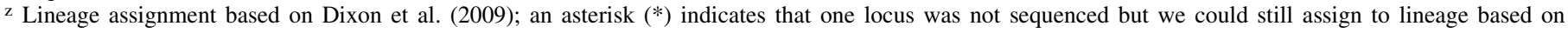
haplotypes of other loci, ns indicates isolate not sequenced, and - indicates isolate sequenced but not assigned to a designated lineage. 
(Shimodaira 2002) test on the ML phylogenies in PAUP* v4.0b10 (Swofford 1998), with resampling estimated log-likelihood of 1,000 bootstrap replicates.

Genetic diversity and haplotype network construction. Isolates of $C$. cassiicola were assigned to populations based on host of origin. The total number of haplotypes $(h)$, haplotype diversity $\left(h_{\mathrm{D}}\right)$, number of segregating sites $(S)$, number of parsimonious sites $(P)$, Watterson's $\Theta\left(\Theta_{\mathrm{w}}\right)$, and nucleotide diversity $(\pi)$ were estimated in DnaSP v.5 (Librado and Rozas 2009) for all isolates and for each population for each locus and for the combined data set. In addition, the minimum number of recombination events for each locus and the combined data set were estimated in DnaSP v.5 using coalescent simulations.

To visualize the evolutionary relationships among $C$. cassiicola isolates while allowing for reticulation events among haplotypes due to recombination or homoplasy, a median network (Bandelt et al. 1995; Posada and Crandall 2001) was constructed on the combined dataset in SplitsTree 4 (Huson and Bryant 2006) using the default settings.

Host range, pathogenicity, and virulence experiments. Forty isolates representing diverse hosts of origin and geographic locations (Table 1) were tested for pathogenicity and aggressiveness on cotton, soybean, tomato, and cucumber. Seedlings were grown in $10-\mathrm{cm}$ pots with a $3: 1$ mixture of fine pine bark to a premixed blend of peat, perlite, lime, and 14-14-14 osmocote fertilizer (The Scotts Company) and maintained in the greenhouse. Cultivars for each host species included the following: cotton $(n=4)$ were DP1252 (DeltaPine), Phy367, Phy427, and Phy499 (Phytogen); soybean $(n=3)$ were A1024631, A1024638 (Asgrow), and 95y70 (Pioneer); tomato $(n=3)$ were Bonny Best (Mountain Valley Seed Co.), FL47, and FL91 (Seminis); and cucumber was Straight 8 (Mountain Valley Seed Co.). Plants were inoculated at the two- to four-true-leaf stage with spore suspensions $(20,000$ conidia/ml $)$ of each isolate, and a water control until runoff. Prior to inoculation, isolates were grown on V8 juice-agar media in 100 -mm Petri dishes for 14 days at $23^{\circ} \mathrm{C}$ with $12 \mathrm{~h}$ of light. Inoculum of each isolate was prepared by scraping the fungal material from five Petri dishes, blending it with sterile distilled $\mathrm{H}_{2} \mathrm{O}$ in a beaker using a Tissumizer, and standardizing the spore concentration with a hemocytometer in a final volume of $300 \mathrm{ml}$. After spray inoculation, each pot was covered with a clear plastic bag for $48 \mathrm{~h}$ to provide high relative humidity. The experiment was arranged in a two-factorial, completely randomized design with three replicate pots, where isolates and host plant species served as factors, and each $10-\mathrm{cm}$ pot contained three seedlings.

Seedlings were evaluated for symptoms 7 days after inoculation using the disease rating system developed by Onesirosan et al. (1975), where $0=$ symptomless, no lesions on leaves or stems; $1=$ weakly virulent or hypersensitive response, few to many nonexpanding pinpoint lesions; 2 = moderately virulent, many expanding lesions, some coalescing but not resulting in a blighting effect; and $3=$ highly virulent, lesions spreading to form large areas of dead tissue, resulting in a blighting effect. Disease incidence was recorded as the proportion of plants per treatment replicate showing symptoms. Disease severity was calculated as the mean disease rating of the three seedlings in each pot. The experiment was conducted twice. Nonparametric analyses were performed using Kruskal-Wallis tests for overall significant differences and Kruskal-Wallis tests for each pair $(\alpha=$ 0.05) in JMP Pro 11 (SAS Institute, Inc.).

\section{RESULTS}

Phylogenetic analyses. To determine the relationship of C. cassiicola isolates from cotton to those from soybean, tomato, Hydrangea spp., pepper, Mandevilla spp., and sesame in the southeastern United States as well as establish the PL to which they belong based on the designations by Dixon et al. (2009), 1,380 nucleotides across four loci (actin, ITS, caa5, and ga4) were sequenced. We included 53 C. cassiicola isolates from the southeastern United States and 23 sequences from previous studies (Déon et al.
2014; Dixon et al. 2009) representing each of the distinct lineages. Phylogenetic trees for each locus and all loci combined generated by BI and ML produced similar topologies. The gene tree topologies were congruent $(P=1.000)$ based on the results of SH tests (Supplementary Fig. S1). Isolates of $C$. cassiicola from cotton in the southeastern United States formed a distinct, well-supported clade (Fig. 1). However, the cotton isolate from Brazil (ATI117) (Déon et al. 2014) was not included in the clade with the U.S. cotton population but grouped with soybean isolates from the United States and Brazil. Isolates from soybean in the southeastern United States were distributed among one well-supported clade consisting of the isolates from Tennessee and two other clusters consisting of isolates from Georgia. The isolates from cotton and soybean from Brazil clustered with some of the Georgia isolates from soybean. The sesame isolate clustered with a soybean isolate from Georgia. All cotton and soybean isolates from the southeastern United States and Brazil grouped within PL1 (Fig. 1). However, the soybean isolate from Guam belonged to PL3.

Cotton, soybean, and sesame isolates were distinct from tomato, pepper, and Mandevilla isolates from the southeastern United States. Isolates from tomato, pepper, and Mandevilla formed a wellsupported clade that clustered in PL4 (Fig. 1) with a tomato isolate from Mississippi (MS31) sequenced in a previous study (Dixon et al. 2009). However, another tomato isolate from American Samoa (AS49) from the same study belonged to PL3 (Fig. 1). Not all isolates from tomato, pepper, and cucumber are included in the phylogeny for the combined loci because we had difficulty amplifying actin for some isolates in this group despite repeated attempts. However, all tomato, cucumber, pepper, and Mandevilla isolates from the southeastern United States formed well-supported clades for the other three loci. Isolates from Hydrangea in the southeastern United States were not identical to any other isolates and belonged to an unknown clade. However, an additional isolate from Hydrangea sampled from Georgia belonged to PL1 based on the three loci caa5, ga4, and ITS.

Genetic diversity and haplotype network. Haplotype and nucleotide diversity, as well as minimum number of recombination events within and among the $C$. cassiicola populations, were calculated (Table 2). The 20 cotton isolates from the southeastern United States are represented by a single haplotype for each locus, with no diversity detected. A single haplotype for three of the loci (ITS, caa5, and ga4) was also observed for the 11 tomato isolates collected for this study. Only two tomato isolates amplified for actin. The single haplotype for the tomato population is different from the single haplotype of the cotton population. For all loci combined, three distinct soybean haplotypes were observed among the 12 isolates collected for this study. The soybean isolate haplotypes are different from the tomato and cotton isolate haplotypes for all loci combined.

For all loci combined across the entire $C$. cassiicola population, there were 27 haplotypes with $87.3 \%$ haplotype diversity and 82 segregating sites across the 1,380 characters. Among the four loci, actin showed the greatest haplotype diversity at $85 \%$, while ITS showed the least at $56.9 \%$. The hypervariable locus caa5 showed the greatest nucleotide diversity in the total $C$. cassiicola population with $\Theta_{w}$ of 0.025 , whereas ITS had the lowest nucleotide diversity with $\Theta_{w}$ of 0.002 . No recombination events were detected within each of the populations from distinct hosts in the southeastern United States However, at minimum, 14 recombination events were detected within the total C. cassiicola population when all loci were combined.

A median network was constructed to determine the evolutionary relationships within and among the $C$. cassiicola populations and to infer recombination within or among populations (Fig. 2). Multiple sets of parallel lines and the occurrence of multiple closed loops, or boxes, among the haplotypes indicate reticulate relationships, suggestive of homoplasy or recombination. PL1, PL2, and PL4 are more diverged lineages, whereas PL3, PL5, and PL6 are more closely related, with extensive reticulation among them. Most 
reticulation events are among rather than within PL; however, there is a single reticulation event within PL1.

Host range, pathogenicity, and virulence. To determine the host range of $C$. cassiicola populations from cotton, soybean, and tomato from the southeastern United States, 40 C. cassiicola isolates were spray inoculated onto different cultivars of cotton, cucumber, soybean, and tomato. Significant differences $(P \leq 0.05)$ were detected in severity and incidence of target spot by isolates from different hosts of origin on inoculated plant hosts (Figs. 3 and 4). Multiple comparison analyses (each pair at $\alpha=0.05$ ) revealed that severity and incidence of $C$. cassiicola isolates were different on each of the inoculated hosts. Among the inoculated hosts, both cotton and tomato were more susceptible to C. cassiicola isolates (Fig. 3A and D). Generally, C. cassiicola was most aggressive when inoculated onto

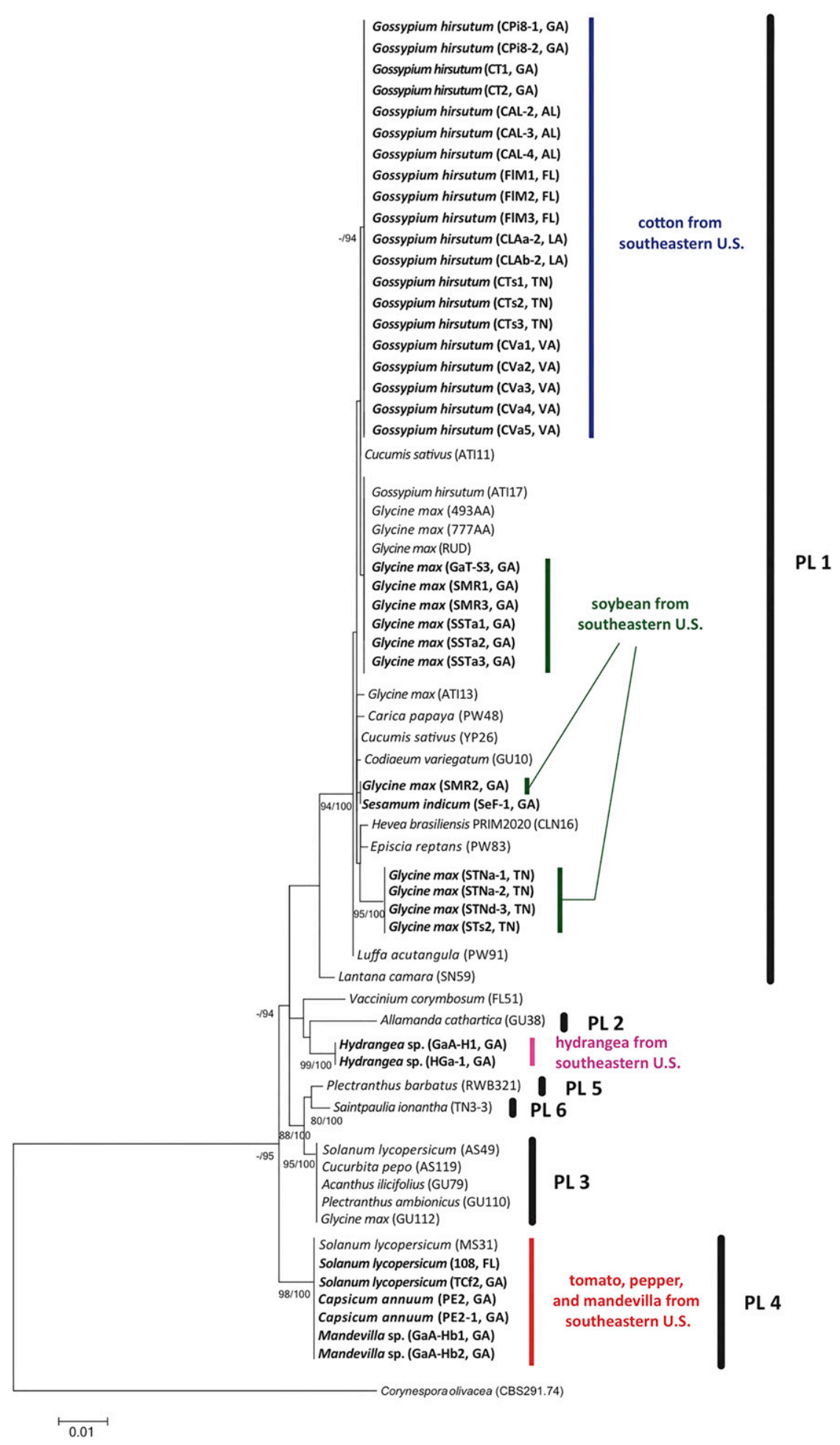

Fig. 1. Maximum-likelihood (ML) consensus tree of Corynespora cassiicola based on combined internal transcribed spacer, actin, caa5, and ga4 loci. The tree generated by Bayesian inference had a similar topology. ML bootstrap values $\geq 70 \%$ are shown before the backslash (/) for each of the supported branches. Posterior probabilities $\geq 90 \%$ are shown after the backslash (/). Symbol - indicates ML bootstrap support $<70 \%$. Isolates we collected and sequenced for this project are indicated in bold. Original host and isolate name are indicated for all isolates. The state where isolates were collected is indicated for isolates in bold. Bold vertical bars in black delineate the phylogenetic lineages (PL) from Dixon et al. (2009). C. olivacea was used as the outgroup. 
the same host as the host of origin (Figs. 3A, C, and D and 4). Isolates from cotton were most aggressive on cotton but less aggressive on other hosts $(P<0.001)$ (Figs. 3 and 4$)$. Additionally, isolates from cotton were more aggressive to cotton seedlings than isolates from other hosts of origin (Figs. 3A and 4A). Cucumber was not susceptible to most isolates (Figs. 3B and 4B). Isolates from soybean were generally more aggressive on soybean than were isolates from other hosts of origin (Fig. 3C and 4C). However, soybean isolates were equally aggressive to soybean, cotton, and tomato $(P=0.329)$. The isolate from cucumber, one of the isolates from pepper, and most of the tomato isolates were more aggressive to tomato than isolates from other hosts of origin. Interestingly, these isolates all share the same haplotype (Fig. 1). Isolates from tomato were moderately aggressive on cotton but not on cucumber or soybean (Figs. 3 and 4).

\section{DISCUSSION}

Populations of $C$. cassiicola from cotton in the southeastern United States are genetically distinct from populations on other hosts in the southeastern United States, including those from soybean and tomato. The cotton isolates were genetically identical to each other and formed a well-supported clade distinct from any other previously characterized $C$. cassiicola populations. The isolates from tomato, pepper, cucumber, and Mandevilla were genetically identical to each other and formed a well-supported clade, yet they were distinct from soybean and cotton isolates. The isolates from soybean were more closely related to isolates from cotton than to tomato isolates, and they formed a more genetically diverse population than those from other hosts in the southeastern United States. Interestingly, the cotton isolate from Brazil (Déon et al. 2014) was more similar to the target spot of soybean populations from the United States and Brazil than to cotton isolates from the United States. Galbieri et al. (2014) reported that genetically identical isolates of $C$. cassiicola were causing outbreaks on cotton and soybean in Brazil. Additional isolates from cotton in Brazil need to be characterized to determine whether the overall population of C. cassiicola causing epidemics on cotton in Brazil is distinct from the population in the United States; however, the C. cassiicola populations from soybean in both countries are genetically similar. In the southeastern United States, populations of $C$. cassiicola showed genetic similarity based on host of origin rather than geographic proximity. This was evident when sampling from different hosts in the same location or the same host across a wide geographic range.

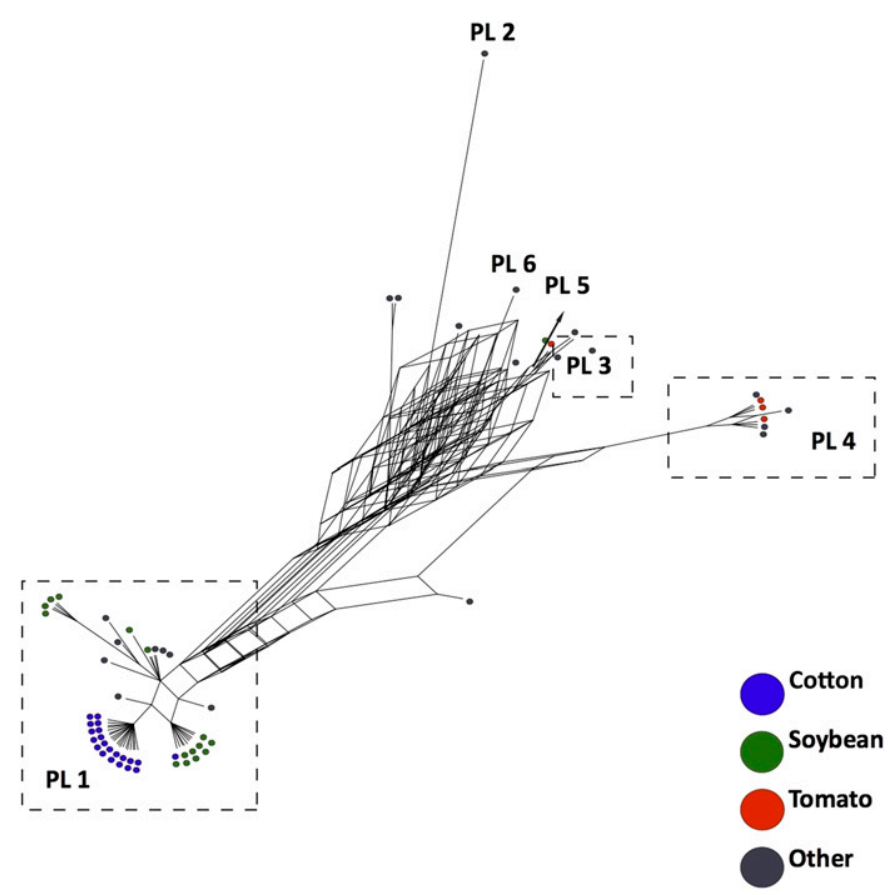

Fig. 2. Median network for Corynespora cassiicola populations from the southeastern United States and representative phylogenetic lineages (PL) from Dixon et al. (2009) based on combined data from the four loci (internal transcribed spacer, actin, caa5, and ga4). Every edge of the network defines a split. Each dot represents an individual isolate, with the shade of each dot representing host of origin, as shown in the key. In reticulate parts of the network, splits are represented by bands of parallel edges or boxes.

TABLE 2. Haplotype diversity, nucleotide diversity, and recombination within and among Corynespora cassiicola populations causing disease on cotton, soybean, and tomato in the southeastern United States

\begin{tabular}{|c|c|c|c|c|c|c|c|}
\hline Locus (number of nucleotides) ${ }^{\mathrm{s}}$ & Population $^{t}$ & $h(n)^{\mathrm{u}}$ & $h_{\mathrm{D}}^{\mathrm{v}}$ & $S(P)^{\mathrm{w}}$ & $\Theta_{w}{ }^{x}$ & $\pi^{\mathrm{y}}$ & $R \min ^{\mathrm{z}}$ \\
\hline \multirow[t]{3}{*}{ ITS (519) } & Total & $5(76)$ & 0.569 & $5(5)$ & 0.002 & 0.002 & 0 \\
\hline & Cotton & $1(20)$ & 0 & $0(0)$ & 0 & 0 & 0 \\
\hline & Soybean & $1(12)$ & 0 & $0(0)$ & 0 & 0 & 0 \\
\hline \multirow[t]{4}{*}{ caa5 (326) } & Total & $17(76)$ & 0.821 & $35(23)$ & 0.025 & 0.020 & 4 \\
\hline & Cotton & $1(20)$ & 0 & $0(0)$ & 0 & 0 & 0 \\
\hline & Soybean & $3(12)$ & 0.621 & $5(4)$ & 0.005 & 0.007 & 0 \\
\hline & Tomato & $1(11)$ & 0 & $0(0)$ & 0 & 0 & 0 \\
\hline & Soybean & $1(12)$ & 0 & $0(0)$ & 0 & 0 & 0 \\
\hline & Tomato & $1(11)$ & 0 & $0(0)$ & 0 & 0 & 0 \\
\hline \multirow[t]{4}{*}{ act (297) } & Total & $16(63)$ & 0.852 & $17(12)$ & 0.013 & 0.010 & 2 \\
\hline & Cotton & $1(20)$ & 0 & $0(0)$ & 0 & 0 & 0 \\
\hline & Soybean & $3(11)$ & 0.618 & $2(2)$ & 0.002 & 0.004 & 0 \\
\hline & Tomato & $1(2)$ & 0 & $0(0)$ & 0 & 0 & 0 \\
\hline Combined $(1,380)$ & Total & $27(63)$ & 0.873 & $82(55)$ & 0.013 & 0.010 & 14 \\
\hline
\end{tabular}

s ITS = internal transcribed spacer.

t Overall number of isolates including representative sequences from Déon et al. (2014) and Dixon et al. (2009).

u Number of haplotypes $(h)$ and the total number of individuals $(n$, in parentheses) included in the analyses.

v Haplotype diversity calculated in DnaSP v.5 (Librado and Rozas 2009).

${ }^{\text {w }}$ Segregating sites $(S)$ and the number of parsimonious sites ( $P$, in parentheses), as calculated in DnaSP v.5.

x Watterson's $\Theta$ calculated in DnaSP v.5.

${ }^{y}$ Nucleotide diversity calculated in DnaSP v.5.

${ }^{\mathrm{z}}$ Minimum number of recombination events calculated in DnaSP v.5. 
Isolates from the same host across a wide geographic range in the southeastern United States, including tomato from Florida, Georgia, and Mississippi and cotton from Georgia, Alabama, Tennessee and Virginia, were identical, whereas isolates from the same location in
Georgia but from different hosts were distinct. The soybean isolates showed some geographic clustering, with isolates from Tennessee forming a distinct clade; however, it is not clear based on the limited sample size whether geographic clustering of soybean samples is
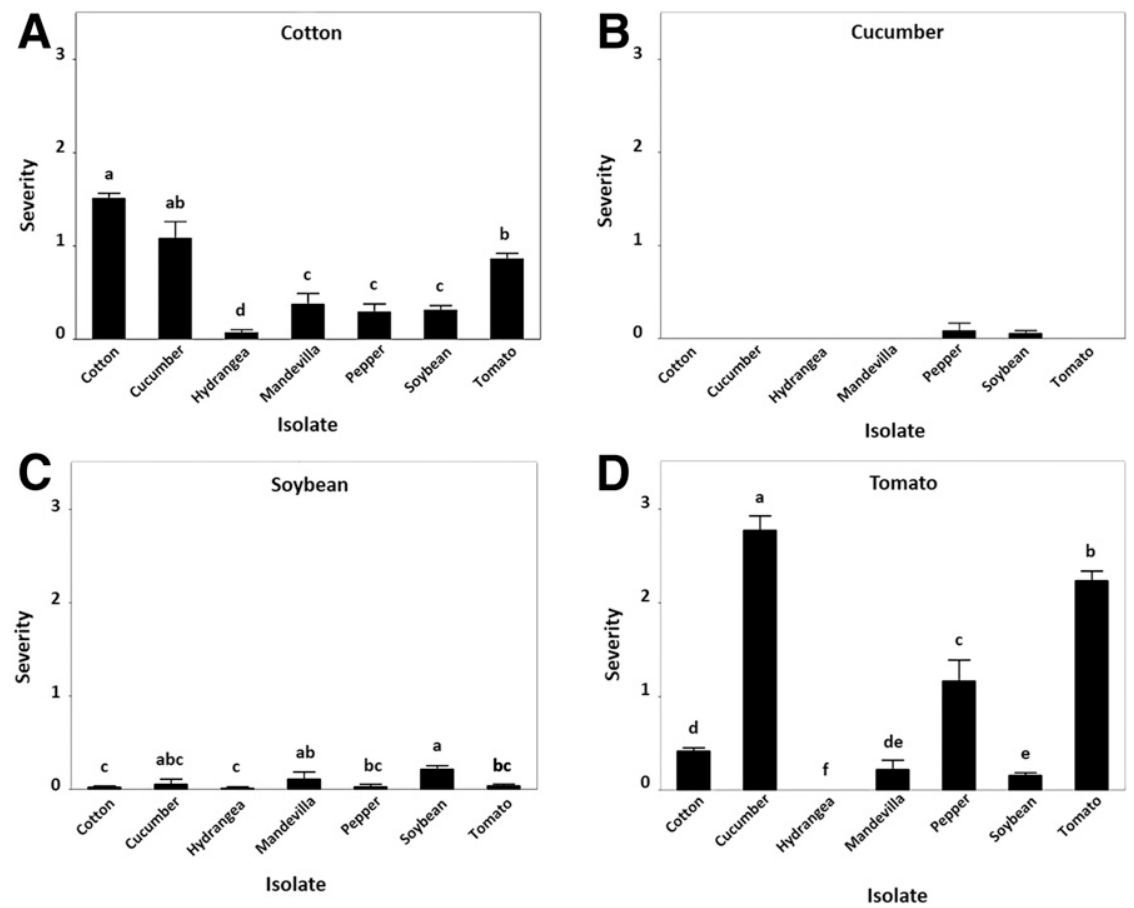

Fig. 3. Mean disease severity of Corynespora cassiicola infection by isolates from different plant hosts onto each host crop, including A, cotton; B, cucumber; C, soybean; and $\mathbf{D}$, tomato. C. cassiicola isolates grouped based on the host of origin (number of isolates for cotton $=16$, cucumber $=1$, Hydrangea $\mathrm{sp}$. $=4$, Mandevilla $\mathrm{sp.}=1$, pepper $=2$, soybean $=9$, and tomato $=7$ ). Treatment bars with the same letter above are not statistically different $($ Kruskal-Wallis nonparametric test at $\alpha=0.05$ ).
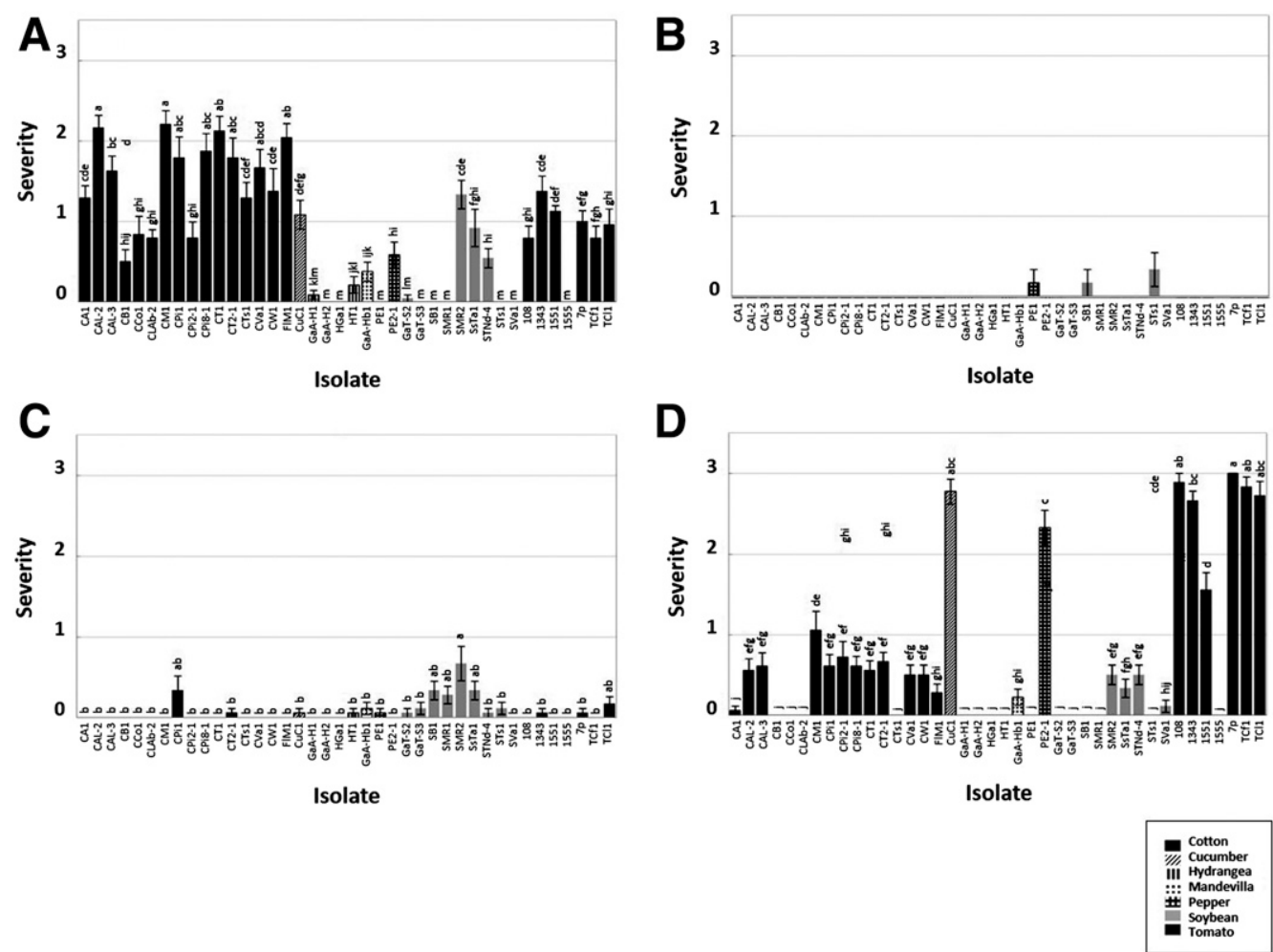

Fig. 4. Mean disease severity of Corynespora cassiicola infection by isolates from different plant hosts onto each host crop, including A, cotton; B, cucumber; C, soybean; and $\mathbf{D}$, tomato. Treatment bars with the same letter above are not statistically different (Kruskal-Wallis nonparametric test at $\alpha=0.05$ ). 
widespread. The target spot epidemics in the southeastern United States on cotton, tomato, and soybean are caused by three genetically distinct populations.

The lack of genetic variation for populations from cotton regardless of geographic location and host cultivar are suggestive of a recent introduction, the evolution of a virulent strain, or as the result of a host shift. The emerging U.S. populations from cotton and tomato were clonal, with no detectable diversity, but populations from soybean and Hydrangea were more diverse. Shrestha et al. (2017) sequenced the genomes of four $C$. cassiicola isolates from cotton and a single isolate from soybean and found very little genetic diversity and no detectable divergence based on single-nucleotide polymorphisms. Sampling of isolates from cotton on other geographic epidemics outside United States could reveal possible sources of introduction; however, the lineages of $C$. cassiicola are so geographically widespread and affect so many hosts that it may be difficult to determine where and on what host lineages originated. Additional studies with larger sample sizes and more polymorphic markers may provide insight into target spot disease emergence in the United States. Increases of target spot in the southeastern United States and worldwide could be due to changes in pathogen virulence, the introduction of aggressive isolates, planting of susceptible host genotypes, or changing environmental conditions (Anderson et al. 2004; Giraud et al. 2010; Stukenbrock and Bataillion 2012; Stukenbrock and McDonald 2008). It is possible that previously described populations of C. cassiicola on cotton, soybean, and tomato have become more aggressive in recent years or that there have been introductions of host-specialized populations.

Pathogenicity and aggressiveness of $C$. cassiicola from the southeastern United States onto different hosts further supported differences in emerging populations on the basis of host of origin. Generally, $C$. cassiicola was most aggressive when inoculated onto the same host as the host of origin, indicating evidence of host specialization. Host specificity was reported by Dixon et al. (2009), especially for $C$. cassiicola to papaya. Surprisingly, cucumber was only mildly susceptible to 3 of the 40 isolates but not to the isolate originally from cucumber. It could be that the cucumber seedlings were inoculated at a stage when they are not susceptible to target spot. The same cucumber cultivar was susceptible to most isolates in a previous study (Dixon et al. 2009); therefore, the environment of the greenhouse or growth stage at inoculation (8 weeks rather than 11 days) may have been more conducive. Target spot on cucumber is not commonly observed in the field in the southeastern United States; thus, an alternative explanation is that isolates from the southeastern United States may not be as aggressive to cucumber as those collected worldwide. Interestingly, the isolate from cucumber was aggressive to tomato and shared the same haplotype as the tomato isolates.

Although C. cassiicola is a necrotroph that can infect numerous host species, it is clear from this study and others (Cutrim and Silva 2003; de Macedo et al. 2013; Dixon et al. 2009; Kingsland 1986; Onesirosan et al. 1974; Pereira et al. 2003) that specific isolates have limited host ranges. This is similar to other necrotrophic plant pathogens such as formae speciales of $F$. oxysporum that are host specialized (Gordon and Martyn 1997; Kistler 1997; van Dam et al. 2016). Further characterization of host-specialized populations of C. cassiicola can help us better understand the mechanisms of host specialization in $C$. cassiicola such as host-selective toxins or necrotrophic effectors (Crook et al. 2012; Friesen and Faris 2012; Friesen et al. 2008; Giraldo and Valent 2013; Selin et al. 2016; Tsuge et al. 2013; Wang et al. 2014), or conditionally dispensable (also known as supernumerary or accessory) chromosomes (Croll and McDonald 2012; Galazka and Freitag 2014; Hartmann et al. 2017; Plissonneau et al. 2017) that could be involved. In the greenhouse study, isolates representing particular haplotypes were able to infect hosts in the greenhouse that were not found infecting the same host in nature. For example, isolates from tomato and soybean caused disease on cotton seedlings in the greenhouse but these haplotypes were never recovered from cotton plants in the field because only the cotton haplotype was found on cotton. This may have been due to growth stage at inoculation, environmental conditions, inoculum level, or another factor that occurred in the greenhouse experiments leading to disease not seen in the field.

We show that $C$. cassiicola isolates from cotton in the southeastern United States cluster in PL1 (Dixon et al. 2009). In addition, isolates from soybean in the southeastern United States also clustered in PL1 along with soybean and cotton isolates from Brazil. All tomato isolates from the United States are in PL4 but some tomato isolates from outside the United States belong to PL3. Network analyses showed reticulations among haplotypes in different PL but only one reticulation event within PL1, which is the most well-represented lineage. The reticulation could result from homoplasy (Crouch et al. 2008; Hovmøller et al. 2008) or from recombination that occurred prior to lineage divergence. We detected evidence of recombination (Table 2) among the populations or lineages from different hosts in the southeastern United States but never within populations or lineages. There are no reports of sexual structures or sexual reproduction in $C$. cassiicola and most studies (Atan and Hamid 2003; Déon et al. 2014; Dixon et al. 2009; Silva et al. 1995, 1998, 2003) show clonal lineages resulting strictly from asexual reproduction.

Understanding the population biology of emerging diseases can lead to improved management strategies (Grünwald and Flier 2005; McDonald 2015; McDonald and Mundt 2016). Information on population structure and levels of diversity within and among populations aid in breeding for resistant cultivars and fungicide management because different populations may have different responses to host genotypes (Milgroom and Peever 2003; Mundt 2014; Twizeyimana et al. 2011; Welch et al. 2018; Zhan et al. 2002) and chemicals (Li and Brewer 2016; Münnekhoff et al. 2017). Because populations of $C$. cassiicola are distinct on different hosts, disease management strategies that most effectively control target spot on cotton, tomato, and soybean may differ.

\section{ACKNOWLEDGMENTS}

We thank T. Faske, A. Fulmer, A. Hagan, H. Kelly, H. Mehl, and P. Price for collecting and providing target spot samples; G. Vallad for providing isolates of $C$. cassiicola; and C. Chan and X. French for their technical assistance.

\section{LITERATURE CITED}

Anderson, P. K., Cunningham, A. A., Patel, N. G., Morales, F. J., Epstein, P. R., and Daszak, P. 2004. Emerging infectious diseases of plants: Pathogen pollution, climate change and agrotechnology drivers. Trends Ecol. Evol. 19:535-544.

Atan, S., and Hamid, N. H. 2003. Differentiating races of Corynespora cassiicola using RAPD and internal transcribed spacer markers. J. Rubber Res. 6:58-64.

Bandelt, H. J., Forster, P. C., Sykes, B., and Richards, M. 1995. Mitochondrial portraits of human-populations using median networks. Genetics 141:743-753.

Bennett, D. 2016. What's known about target spot in soybeans? Online publication. Delta Farm Press. http://www.deltafarmpress.com/soybeans/whats-known-about-target-spot-soybeans

Blazquez, C. 1967. Corynespora leaf spot of cucumber. Pages 177-182 in: Proc. Fla. State Hortic. Soc.

Blazquez, C. 1972. Target spot of tomato. Plant Dis. Rep. 56:243.

Butler, D. 2013. Fungus threatens top banana. Nature 504:195-196.

Butler, S., Young-Kelly, H., Raper, T., Cochran, A., Jordan, J., Shrestha, S., Lamour, K., Mengistu, A., Castro-Rocha, A., and Shelby, P. 2016. First report of target spot caused by Corynespora cassiicola on cotton in Tennessee. Plant Dis. 100:535.

Campbell, H. L., Hagan, A., Bowen, K., and Nightengale, S. P. 2012. Pages 18-19 in: Corynespora Leaf Spot: A New Disease in Alabama Cotton. American Phytopathological Society, St. Paul, MN.

Carbone, I., and Kohn, L. 1999. A method for designing primer sets for speciation studies in filamentous ascomycetes. Mycologia 91:553-556.

Carris, L., Glawe, D., and Gray, L. 1986. Isolation of the soybean pathogens Corynespora cassiicola and Phialophora gregata from cysts of Heterodera glycines in Illinois. Mycologia 78:503-506.

Chee, K. 1990. Present status of rubber diseases and their control. Rev. Plant Pathol. 69:423-430. 
Collado, J., Platas, G., Gonzalez, I., and Pelaez, F. 1999. Geographical and seasonal influences on the distribution of fungal endophytes in Quercus ilex. New Phytol. 144:525-532.

Conner, K. N., Hagan, A. K., and Zhang, L. 2013. First report of Corynespora cassiicola-incited target spot on cotton in Alabama. Plant Dis. 97:1379.

Croll, D., and McDonald, B. A. 2012. The accessory genome as a cradle for adaptive evolution in pathogens. PLoS Pathog. 8:e1002608.

Crook, A. D., Friesen, T. L., Liu, Z. H., Ojiambo, P. S., and Cowger, C. 2012. Novel necrotrophic effectors from Stagonospora nodorum and corresponding host sensitivities in winter wheat germplasm in the southeastern United States. Phytopathology 102:498-505.

Crouch, J. A., Glasheen, B. M., Giunta, M. A., Clarke, B. B., and Hillman, B. I. 2008. The evolution of transposon repeat-induced point mutation in the genome of Colletotrichum cereale: Reconciling sex, recombination and homoplasy in an "asexual" pathogen. Fungal Genet. Biol. 45:190-206.

Cutrim, F. A., and Silva, G. S. 2003. Pathogenicity of Corynespora cassiicola to different plant species. Fitopatol. Bras. 28:193-194.

de Macedo, D. M., Pereira, O. L., Wheeler, G. S., and Barreto, R. W. 2013. Corynespora cassiicola $\mathrm{f}$. sp. schinii, a potential biocontrol agent for the weed Schinus terebinthifolius in the United States. Plant Dis. 97:496-500.

Déon, M., Fumanal, B., Gimenez, S., Bieysse, D., Oliveira, R. R., Shuib, S. S., Breton, F., Elumalai, S., Vida, J. B., Seguin, M., Leroy, T., Roeckel-Drevet, P., and Pujade-Renaud, V. 2014. Diversity of the cassiicolin gene in Corynespora cassiicola and relation with the pathogenicity in Hevea brasiliensis. Fungal Biol. 118:32-47.

Déon, M., Scomparin, A., Tixier, A., Mattos, C. R., Leroy, T., Seguin, M., Roeckel-Drevet, P., and Pujade-Renaud, V. 2012. First characterization of endophytic Corynespora cassiicola isolates with variant cassiicolin genes recovered from rubber trees in Brazil. Fungal Divers. 54:87-99.

Dixon, L. J., Schlub, R. L., Pernezny, K., and Datnoff, L. E. 2009. Host specialization and phylogenetic diversity of Corynespora cassiicola. Phytopathology 99:1015-1027.

Edmisten, K. 2012. Target leaf spot found in North Carolina cotton. Online publication. Southeast Farm Press. http://www.southeastfarmpress.com/ cotton/target-leaf-spot-found-north-carolina-cotton

Farr, D. F., and Rossman, A. Y. 2017. Fungal Databases, U.S. National Fungus Collections. Online publication. United States Department of AgricultureAgricultural Research Service. https://nt.ars-grin.gov/fungaldatabases/

Faske, T. 2016. Arkansas soybeans: Target spot-What do we know? Online publication. Agfax. https://agfax.com/2016/11/02/arkansas-soybeans-targetspot-what-do-we-know/

Fisher, M. C., Henk, D. A., Briggs, C. J., Brownstein, J. S., Madoff, L. C., McCraw, S. L., and Gurr, S. J. 2012. Emerging fungal threats to animal, plant and ecosystem health. Nature 484:186-194.

Friesen, T. L., and Faris, J. D. 2012. Characterization of plant-fungal interactions involving necrotrophic effector-producing plant pathogens. Pages 191-207 in: Methods in Molecular Biology (Methods and Protocols), Vol. 35. M. Bolton and B. Thomma, eds. Humana Press, Clifton, NJ.

Friesen, T. L., Faris, J. D., Solomon, P. S., and Oliver, R. P. 2008. Host-specific toxins: Effectors of necrotrophic pathogenicity. Cell. Microbiol. 10:1421-1428.

Fulmer, A. M., Walls, J. T., Dutta, B., Parkunan, V., Brock, J., and Kemerait, R. C. 2012. First report of target spot caused by Corynespora cassiicola on cotton in Georgia. Plant Dis. 96:1066.

Galazka, J. M., and Freitag, M. 2014. Variability of chromosome structure in pathogenic fungi - of "ends and odds". Curr. Opin. Microbiol. 20:19-26.

Galbieri, R., Araújo, D. C., Kobayasti, L., Girotto, L., Matos, J. N., Marangoni, M. S., Almeida, W., and Mehta, Y. R. 2014. Corynespora leaf blight of cotton in Brazil and its management. Am. J. Plant Sci. 5: Article ID 52490.

Giraldo, M. C., and Valent, B. 2013. Filamentous plant pathogen effectors in action. Nat. Rev. Microbiol. 11:800-814.

Giraud, T., Gladieux, P., and Gavrilets, S. 2010. Linking the emergence of fungal plant diseases with ecological speciation. Trends Ecol. Evol. 25: 387-395.

Gordon, T. R., and Martyn, R. D. 1997. The evolutionary biology of Fusarium oxysporum. Annu. Rev. Phytopathol. 35:111-128.

Grünwald, N. J., and Flier, W. G. 2005. The biology of Phytophthora infestans at its center of origin. Annu. Rev. Phytopathol. 43:171-190.

Hagan, A. 2014. Target spot management options in Alabama. Page 18 in: 2014 Beltwide Cotton Conf.

Harrington, T. C., Yun, H. Y., Lu, S. S., Goto, H., Aghayeva, D. N., and Fraedrich, S. W. 2011. Isolations from the redbay ambrosia beetle, Xyleborus glabratus, confirm that the laurel wilt pathogen, Raffaelea lauricola, originated in Asia. Mycologia 103:1028-1036.

Hartmann, F. E., Sánchez-Vallet, A., McDonald, B. A., and Croll, D. 2017. A fungal wheat pathogen evolved host specialization by extensive chromosomal rearrangements. ISME J. 11:1189-1204.

Hovmøller, M. S., Yahyaoui, A. H., Milus, E. A., and Justesen, A. F. 2008. Rapid global spread of two aggressive strains of a wheat rust fungus. Mol. Ecol. 17:3818-3826.
Huang, H.-K., Liu, C.-E., Liou, J.-H., Hsiue, H.-C., Hsiao, C.-H., and Hsueh, P.-R. 2010. Subcutaneous infection caused by Corynespora cassiicola, a plant pathogen. J. Infect. 60:188-190.

Huson, D. H., and Bryant, D. 2006. Application of phylogenetic networks in evolutionary studies. Mol. Biol. Evol. 23:254-267.

Jones, J. P. 1961. A leaf spot of cotton caused by Corynespora cassiicola. Phytopathology 51:305-308.

Kingsland, G. C. 1986. Pathogenicity and epidemiology of Corynespora cassiicola in the Republic of Seychelles. Trop. Pest Manage. 32:283-287.

Kistler, H. C. 1997. Genetic diversity in the plant-pathogenic fungus Fusarium oxysporum. Phytopathology 87:474-479.

Koenning, S. R., Creswell, T. C., Dunphy, E. J., Sikora, E. J., and Mueller, J. D. 2006. Increased occurrence of target spot of soybean caused by Corynespora cassiicola in the southeastern United States. Plant Dis. 90:974.

Lee, S. 1988. A rapid high yield mini-prep method for isolation of total genomic DNA from fungi. Fungal Genet. Newsl. 35:23-24.

Lee, S., Mel'nik, V., Taylor, J. E., and Crous, P. W. 2004. Diversity of saprobic hyphomycetes on Proteaceae and Restionaceae from South Africa. Fungal Divers. 17:91-114.

Li, H. X., and Brewer, M. T. 2016. Spatial genetic structure and population dynamics of gummy stem blight fungi within and among watermelon fields in the southeastern United States. Phytopathology 106:900-908.

Librado, P., and Rozas, J. 2009. DnaSP v5: A software for comprehensive analysis of DNA polymorphism data. Bioinformatics 25:1451-1452.

Mahgoub, E. 1969. Corynespora cassiicola, a new agent of maduromycetoma. J. Trop. Med. Hyg. 72:218-221.

Mayfield, A. E., Smith, J. A., Hughes, M., and Dreaden, T. J. 2008. First report of laurel wilt disease caused by a Raffaelea sp. on avocado in Florida. Plant Dis. 92:976.

McDonald, B. A. 2015. How can research on pathogen population biology suggest disease management strategies? The example of barley scald (Rhynchosporium commune). Plant Pathol. 64:1005-1013.

McDonald, B. A., and Mundt, C. C. 2016. How knowledge of pathogen population biology informs management of Septoria tritici blotch. Phytopathology 106:948-955.

Mehl, H. L., and Phipps, P. M. 2013. Applied Research on Field Crop Disease Control. Virginia Polytechnic Institute and State University, College of Agriculture and Life Sciences, Tidewater Agricultural Research \& Extension Center, Suffolk.

Milgroom, M. G., and Peever, T. L. 2003. Population biology of plant pathogens: The synthesis of plant disease epidemiology and population genetics. Plant Dis. 87:608-617.

Mundt, C. C. 2014. Durable resistance: A key to sustainable management of pathogens and pests. Infect. Genet. Evol. 27:446-455.

Münnekhoff, A. K., Linde, M., and Debener, T. 2017. The gene diversity pattern of Diplocarpon rosae populations is shaped by the age, diversity and fungicide treatment of their host populations. Plant Pathol. 66:1288-1298.

Newsam, A. 1960. Page 63 in: Plant Pathology Division Report. Rubber Research Institute of Malaysia, Kuala Lumpur, Malaysia.

Olive, L. S., Bain, D. C., and Lefebvre, C. L. 1945. A leaf spot of cowpea and soybean caused by an undescribed species of Helminthosporium. Phytopathology 35:822-831.

Onesirosan, P., Mabuni, C. T., Durbin, R. D., Morin, R. B., Rich, D. H., and Arny, D. C. 1975. Toxin production by Corynespora cassiicola. Physiol. Plant Pathol. 5:289-295.

Onesirosan, P. T., Arny, D. C., and Durbin, R. 1974. Host specificity of Nigerian and North American isolates of Corynespora cassiicola. Phytopathology 64:1364-1367.

Plissonneau, C., Benevenuto, J., Mohd-Assaad, N., Fouché, S., Hartmann, F. E., and Croll, D. 2017. Using population and comparative genomics to understand the genetic basis of effector-driven fungal pathogen evolution. Front. Plant Sci. 8:119.

Pereira, J. M., Barreto, R. W., Ellison, C. A., and Maffia, L. A. 2003. Corynespora cassiicola f. sp. lantanae: A potential biocontrol agent from Brazil for Lantana camara. Biol. Control 26:21-31.

Posada, D., and Crandall, K. A. 2001. Intraspecific gene genealogies: Trees grafting into networks. Trends Ecol. Evol. 16:37-45.

Price, T., Singh, R., and Fromme, D. 2015. First report of target spot caused by Corynespora cassiicola in Louisiana cotton. Plant Health Prog. 16:223-224.

Promputtha, I., Lumyong, S., Dhanasekaran, V., McKenzie, E. H. C., Hyde, K. D., and Jeewon, R. 2007. A phylogenetic evaluation of whether endophytes become saprotrophs at host senescence. Microb. Ecol. 53: 579-590.

Qi, Y.-X., Zhang, X., Pu, J.-J., Liu, X.-M., Lu, Y., Zhang, H., Zhang, H.-Q., Lv, Y.-C., and Xie, Y.-X. 2011. Morphological and molecular analysis of genetic variability within isolates of Corynespora cassiicola from different hosts. Eur. J. Plant Pathol. 130:83-95.

Ronquist, F., and Huelsenbeck, J. P. 2003. MrBayes 3: Bayesian phylogenetic inference under mixed models. Bioinformatics 19:1572-1574. 
Schlub, R., Smith, L. J., Datnoff, L., and Pernezny, K. 2009. An overview of target spot of tomato caused by Corynespora cassiicola. Pages $25-28$ in: II Int. Symp. Tomato Dis.

Selin, C., de Kievit, T. R., Belmonte, M. F., and Fernando, W. G. D. 2016. Elucidating the role of effectors in plant-fungal interactions: Progress and challenges. Front. Microbiol. 7:600.

Shimodaira, H. 2002. An approximately unbiased test of phylogenetic tree selection. Syst. Biol. 51:492-508.

Shimomoto, Y., Sato, T., Hojo, H., Morita, Y., Takeuchi, S., Mizumoto, H., Kiba, A., and Hikichi, Y. 2011. Pathogenic and genetic variation among isolates of Corynespora cassiicola in Japan. Plant Pathol. 60:253-260.

Shrestha, S. K., Lamour, K., and Young-Kelly, H. 2017. Genome sequences and SNP analyses of Corynespora cassiicola from cotton and soybean in the southeastern United States reveal limited diversity. PLoS One 12:e0184908.

Silva, W. P., Karunanayake, E. H., Wijesundera, R. L., and Priyanka, U. M. 2003. Genetic variation in Corynespora cassiicola: A possible relationship between host origin and virulence. Mycol. Res. 107:567-571.

Silva, W. P. K., Deverall, B. J., and Lyon, B. R. 1998. Molecular, physiological and pathological characterization of Corynespora leaf spot fungi from rubber plantations in Sri Lanka. Plant Pathol. 47:267-277.

Silva, W. P. K., Multani, D., Deverall, B. J. and Lyon, B. R. 1995. RFLP and RAPD analyses in the identification and differentiation of isolates of the leaf spot fungus Corynespora cassiicola. Aust. J. Bot. 43:609-618.

Singh, R. P., Hodson, D. P., Jin, Y., Huerta-Espino, J., Kinyua, M. G., Wanyera, R., Njau, P. and Ward, R. W. 2006. Current status, likely migration and strategies to mitigate the threat to wheat production from race $\mathrm{Ug} 99$ (TTKS) of stem rust pathogen. CAB Rev. 1:1-13.

Stukenbrock, E. H., and Bataillon, T. 2012. A population genomics perspective on the emergence and adaptation of new plant pathogens in agro-ecosystems. PLoS Pathog. 8:e1002893.

Stukenbrock, E. H., and McDonald, B. A. 2008. The origins of plant pathogens in agro-ecosystems. Annu. Rev. Phytopathol. 46:75-100.

Suryanarayanan, T. S., Murali, T. S., and Venkatesan, G. 2002. Occurrence and distribution of fungal endophytes in tropical forests across a rainfall gradient. Can. J. Bot. 80:818-826.

Swofford, D. 1998. PAUP* 4.0 Beta Version. Sinauer, Sunderland, MA.
Tamura, K., Peterson, D., Peterson, N., Stecher, G., Nei, M., and Kumar, S. 2011. MEGA5: Molecular evolutionary genetics analysis using maximum likelihood, evolutionary distance, and maximum parsimony methods. Mol. Biol. Evol. 28:2731-2739.

Thompson, J. D., Gibson, T. and Higgins, D. G. 2002. Multiple sequence alignment using ClustalW and ClustalX. Pages 2.3.1-2.3.22 in: Current Protocols in Bioinformatics, Vol. 00. John Wiley \& Sons, Inc., Hoboken, NJ.

Tsuge, T., Harimoto, Y., Akimitsu, K., Ohtani, K., Kodama, M., Akagi, Y., Egusa, M., Yamamoto, M., and Otani, H. 2013. Host-selective toxins produced by the plant pathogenic fungus Alternaria alternata. FEMS Microbiol. Rev. 37:44-66.

Twizeyimana, M., Ojiambo, P. S., Haudenshield, J. S., Caetano-Anollés, G., Pedley, K. F., Bandyopadhyay, R., and Hartman, G. L. 2011. Genetic structure and diversity of Phakopsora pachyrhizi isolates from soyabean. Plant Pathol. 60:719-729.

van Dam, P., Fokkens, L., Schmidt, S. M., Linmans, J. H., Kistler, H. C., Ma, L. J., and Rep, M. 2016. Effector profiles distinguish formae speciales of Fusarium oxysporum. Environ. Microbiol. 18:4087-4102.

Wang, X., Jiang, N., Liu, J., Liu, W., and Wang, G.-L. 2014. The role of effectors and host immunity in plant-necrotrophic fungal interactions. Virulence 5:722-732.

Wei, Y. X., Zhang, H., Pu, J. J. and Liu, X. M. 2014. First report of target spot of cotton caused by Corynespora cassiicola in China. Plant Dis. 98:1006.

Welch, T., Feechan, A., and Kildea, S. 2018. Effect of host resistance on genetic structure of core and accessory chromosomes in Irish Zymoseptoria tritici populations. Eur. J. Plant Pathol. 150:139-148.

White, T. J., Bruns, T., Lee, S., and Taylor, J. 1990. Amplification and direct sequencing of fungal ribosomal RNA genes for phylogenetics. Pages 315-322 in: PCR Protocols, a Guide to Methods and Applications. Academic Press, Inc., New York.

Wrather, J. A., Anderson, T. R., Arsyad, D. M., Tan, Y., Ploper, L. D., Porta-Puglia, A., Ram, H. H., and Yorinori, J. T. 2001. Soybean disease loss estimates for the top ten soybean-producing countries in 1998. Can. J. Plant Pathol. 23:115-121.

Zhan, J., Mundt, C. C., Hoffer, M. E., and McDonald, B. A. 2002. Local adaptation and effect of host genotype on the rate of pathogen evolution: An experimental test in a plant pathosystem. J. Evol. Biol. 15:634-647. 